Center for

Ouantitative

Economics

\title{
The Other January Effect: International Evidence ${ }^{\dagger}$
}

\author{
Martin T. Bohl and Christian A. Salm ${ }^{\ddagger}$
}

$8 / 2009$

${ }^{\dagger}$ European Journal of Finance, forthcoming

${ }^{\ddagger}$ Department of Economics, University of Münster, Germany

wissen.leben

WWU Münster 


\title{
The Other January Effect: International Evidence*
}

\author{
Martin T. Bohl ${ }^{\dagger}$ and Christian A. Salm \\ Westfälische Wilhelms-University Münster, Germany
}

April 3, 2009

\begin{abstract}
This paper investigates the predictive power of stock market returns in January for the subsequent eleven months' returns across 19 countries, thereby contributing to the literature on stock market seasonalities. Only two out of 19 countries' stock markets exhibit a robust Other January Effect. In light of this evidence, we conclude that the Other January Effect is not an international phenomenon.
\end{abstract}

JEL Classification: G10, G11, G12, G14

Keywords: Stock market efficiency, Other January Effect, Stock market anomalies

*The authors would like to thank Farooq Akram, Malik Bensafta, Gernot Doppelhofer, Andrew Filardo, Eric Gerardin, Uwe Hassler, Neil Kellard, Erik Kole, Jörg Lingens, Judith Lischewski, Dieter Nautz, Paolo Pasquariello, Michael Schuppli, Pierre Siklos, Sarah Stölting, David Sondermann, Genaro Sucarrat, Mark Trede, Martin Uebele, Bernd Wilfling, Yangru Wu, two anonymous referees and seminar participants at the Westfälische Wilhelms-University Münster, at the workshop on Fundamental and Non-Fundamental Asset Price Dynamics (Venstul) and at the 15th International Forecasting Financial Markets Conference (Aix-en-Provence). Martin T. Bohl is also grateful to the Alexander von Humbold foundation for financial support.

${ }^{\dagger}$ Corresponding author: Martin T. Bohl, Department of Economics, Westfälische Wilhelms-University Münster, Am Stadtgraben 9, D-48143 Münster, Germany, Fax: +49-251-83-22846, Phone: +49-251-8325005, E-mail address: martin.bohl@wiwi.uni-muenster.de. 


\title{
The Other January Effect: International Evidence
}

\begin{abstract}
This paper investigates the predictive power of stock market returns in January for the subsequent eleven months' returns across 19 countries, thereby contributing to the literature on stock market seasonalities. Only two out of 19 countries' stock markets exhibit a robust Other January Effect. In light of this evidence, we conclude that the Other January Effect is not an international phenomenon.
\end{abstract}

JEL Classification: G10, G11, G12, G14

Keywords: Stock market efficiency, Other January Effect, Stock market anomalies 
"October. This is one of the peculiarly dangerous months to speculate in stocks. The others are July, January, September, April, November, May, March, June, December, August, and February." (Mark Twain (1894))

\section{Introduction}

Since the late 1970s, a large body of research in finance has questioned the efficient markets hypothesis. Recently, Cooper et al. (2006) report significant predictive power of January stock market returns in the U.S. for returns in the remainder of the calendar year and thus confirm the market wisdom 'As goes January, so goes the year'. We investigate the presence of the Other January Effect in 19 countries, thereby broadening empirical evidence to stock markets with dissimilar institutional and regulatory characteristics. By reducing the datasnooping bias, we ascertain whether the Other January Effect is a real phenomenon. While the results for the U.S. are confirmed, we do not find empirical evidence supporting the Other January Effect for most of the other 18 countries in our sample.

The Other January Effect was first discovered for the U.S. by Yale Hirsch in 1972 (Hirsch and Hirsch (2007)) and termed the January Barometer. Hirsch and Hirsch (2007) report a 91.1\% accuracy ratio for this barometer for S\&P 500 data since 1950, with extreme events such as wars being responsible for the exceptions to the rule. They identify major political events as the fundamental force driving the January Barometer. These are the conventions of the new Congresses, the President's State of the Union message, the presentation of the annual budget of the government, and the setting of national goals and priorities by the President. In the U.S., these political events occur in January, and Hirsch and Hirsch (2007) hypothesise that moving such incidents to other months could eliminate the January Barometer. However, as they address mainly practitioners, they do not conduct a rigorous econometric investigation of the phenomenon.

Bloch and Pupp (1983) test for the January Barometer with S\&P 500 data from 1950 to 1982. Once controlled for long-term overall upward trends in the stock market, the January Barometer does not have statistically significant forecasting power. Consistently, Fuller (1978) reports that a trading strategy based on the January Barometer is as profitable as a naive buy-and-hold strategy. By contrast, Hensel and Ziemba (1995a) propose a trading

rule for the U.S. market that recommends buying after a positive January return, whereas 
no conclusive investment advice can be derived from a negative return in January. Hensel and Ziemba (1995b) investigate the January Barometer's forecasting power internationally. They confirm their earlier results for the U.S. and find predictive power of the January Barometer when January returns are positive for Australia, Canada, Japan, and the U.K. Hensel and Ziemba (1995b) attribute the January Barometer to economic activity such as Christmas sales. Using data from the New York Stock Exchange, Brown and Juo (2006) find that negative January returns are a reliable predictor for the rest of the year, while positive January returns' predictive power is much weaker.

Cooper et al. (2006) provide the first thorough econometric investigation of the Other January Effect. They examine value-weighted and equally-weighted CRSP market returns from 1940 to 2003 and stock market return time series for the NYSE index from 1825 to 2003. In their analysis, macroeconomic and business cycle variables, the Presidential cycle, and investor sentiment indices are accounted for as control variables. The stock market returns in January reliably predict the return for the rest of the year, while the stock market returns in the other eleven months cannot predict future returns.

Seemingly significant calendar effects in stock markets can be the result of extensive search for abnormal patterns in non-experimental and limited datasets (Sullivan et al. (2001)). Apparent deviations from unpredictable stock returns are deemed surprising and hence journals publish disproportionately more papers reporting irregularities. In particular, the Other January Effect might be the result of snooping the U.S. stock market data for such an anomaly. Moreover, Lo and MacKinlay (1990) and Sullivan et al. (2001) argue that statistical inference based on the empirical properties of a particular sample is prone to data-snooping biases and hence potentially misleading. Instead of waiting decades until reinvestigating the Other January Effect with new data for the U.S. as indicated by Cooper et al. (2006), we, alternatively, make a contribution by using existent data from other countries as Schwert (2003) suggests.

Following this approach, we analyse 18 additional stock markets whose return-generating processes are largely independent of each other, thereby reducing any data-snooping bias. Moreover, we construct a set of control variables to capture calendar anomalies as well as varying risk premia due to business cycle fluctuations. Specifically, we raise the research question of whether the Other January Effect is an international phenomenon or a peculiarity of the U.S. stock market. 
The paper is organized as follows. We introduce the methodology in section 2 and the dataset in section 3. Section 4 presents the empirical results before section 5 summarises our findings and concludes.

\section{Methodology}

To test the statistical significance of the Other January Effect, we follow the methodology proposed by Cooper et al. (2006). We compare monthly stock market returns over eleven months following positive Januarys with monthly stock market returns in the eleven months following negative Januarys by estimating

$$
r_{t}=\alpha+\beta O J E_{t}+\gamma X_{t}+\phi Z_{t-1}+u_{t}
$$

where $r_{t}$ is the excess stock market return, $\alpha$ the constant, $O J E_{t}$ the dummy variable to identify the Other January Effect, $X_{t}$ and $Z_{t-1}$ vectors of control variables, and $u_{t}$ the error term.

The indicator variable $O J E_{t}$ takes the value of 1 for February to December following Januarys with positive excess stock returns and 0 otherwise. If the estimated coefficient of the dummy variable is statistically significantly different from 0 and positive, the 11-month holding-period return following a positive January return is significantly higher than the 11month return following a negative January return. This implies that January stock returns have predictive power for the returns in the following eleven months.

Januarys' predictive power might be associated with other variables and phenomena which potentially explain stock returns. Therefore, we take contemporaneous and lagged control variables in the vectors $X_{t}$ and $Z_{t-1}$ into account. ${ }^{1}$ The contemporaneous vector $X_{t}$ contains a dummy variable capturing the Halloween Effect put forward by Bouman and Jacobsen (2002). International evidence indicates that returns for May to October are substantially lower than for the rest of the calendar year. Therefore, the Halloween indicator variable $H a l l D_{t}$ takes the value 1 for each month from November to April and 0 for the remaining months.

The lagged vector $Z_{t-1}$ comprises ex ante observable variables related to the business cycle and international stock market dependencies. Four lagged macroeconomic control variables

\footnotetext{
${ }^{1}$ The impact of outliers is also considered. In particular we control for the large monthly declines of stock markets in October 1987 and in September 2001. Including an outlier dummy variable does not qualitatively affect the empirical results.
} 
related to the business cycle are included in $Z_{t-1}$. The variables are possible proxies for time varying risk premia on stocks. These variables are:

1. lagged dividend yield $D I V_{t-1}$;

2. lagged term spread $T E R M_{t-1}$, measured as the difference between a long-term government bond yield and the short-term interest rate;

3. lagged relative interest rate $R R E L_{t-1}$, which is calculated as the deviation of the short-term interest rate from its one-year moving

4. expected inflation $I N F_{t-1}^{e}$ formed in $t-1$ for period $t$, which is proxied by actual inflation in period $t .^{2}$

There is broad evidence that those control variables can forecast stock returns (Fama and French (1988, 1986), Campbell and Shiller (1988), Chen et al. (1986), Keim and Stambaugh (1986) and Jensen et al. (1996)). Finally, for all markets except the U.S., lagged U.S. stock market returns $r_{t-1}^{U S}$ are included to capture the linkages between the U.S. stock market and the markets in other countries. ${ }^{3}$

We start by estimating an unrestricted model which consists of the indicator variable $O J E_{t}$ and the full set of controls. Applying the general-to-specific methodology we reduce the complexity of the unrestricted model and provide a robustness check for our empirical results. Specifically, we start with all candidate variables and stepwise eliminate control variables with coefficients that are not statistically significant at the $10 \%$ level. This leads to a specific model with only statistically significant coefficient estimates for the control variables. Campbell and Yogo (2006) argue that statistical inference in predictive regressions using persistent explanatory variables, like the dividend yield, is potentially invalid. As a robustness check, we estimate regressions without the vectors of control variables. ${ }^{4}$

The regression equations are estimated using ordinary least squares (OLS). The standard errors are corrected for heteroskedasticity in the residuals using the method proposed by

\footnotetext{
${ }^{2}$ The lagged default spread, which is defined as the difference between the return on a portfolio of corporate bonds and on long-term government bonds, was also considered as a macroeconomic control variable. Since returns on corporate bonds are available for much shorter sample periods for most countries this variable was omitted from our baseline regression in order to increase the sample length. The empirical findings additionally using the lagged default spread in the shorter sample periods do not affect our main conclusion.

${ }^{3}$ To control for joint effects and comovements, contemporaneous U.S. stock market returns $r_{t}^{U S}$ are added to the set of control variables. The variable appears to be statistical significant for many countries but the empirical findings on the Other January Effect are unaffected.

${ }^{4}$ In addition, we also run the general-to-specific procedure starting with all candidate variables without lagged dividend yield. The empirical results confirm the robustness of the main results.
} 
White (1980). ${ }^{5}$ In order to strengthen statistical inference and to control for data-snooping biases, we use standard errors which are obtained from the randomized-bootstrap procedure with 10,000 replications suggested by Cooper et al. (2006). This bootstrap procedure explicitly controls for the predictive power of stock returns in the remaining eleven month. The characteristics of the randomized-bootstrap procedure are described in detail in the paper by Cooper et al. (2006).

\section{Data}

Our dataset comprises monthly observations on stock market indices and macroeconomic variables for 19 major industrialized countries with mature stock markets: Australia, Austria, Belgium, Canada, Denmark, Finland, France, Germany, Italy, Japan, the Netherlands, Norway, South Africa, South Korea, Spain, Sweden, Switzerland, the U.K., and the U.S. The selection of these countries is motivated by data availability. To obtain a sufficient long common sample period for the empirical investigation, only countries are considered where data is available at least from 1970. All stock market and macroeconomic time series are denominated in local currency units. Sample periods vary across variables and countries. For each country we select the longest common sample for the whole set of stock market and macroeconomic variables.

Stock market returns for each country are calculated using value-weighted total return indices. Fama (1998) argues that value-weighted returns, rather than equal-weighted returns, are the appropriate data to test for an anomaly as they replicate investment performance. The excess stock return in \% per month is calculated as

$$
r_{t}=\left(\ln \left(I_{t} / I_{t-1}\right)-\ln \left(1+\frac{i_{t}^{s}}{12 \cdot 100}\right)\right) \cdot 100,
$$

where $I_{t}$ is the value of the performance index and $i_{t}^{s}$ is the short-term interest rate in $\%$ per annum. We use simple compounded dividend yields $D Y_{t}$ and compute continuously compounded dividend yields $D I V_{t}=\ln \left(1+D Y_{t}\right) \cdot 100$. Depending on country specific availability, we use the Treasury bill rate, the central bank discount rate, commercial paper yields or, alternatively, the money market rate, as the short-term interest rate. The longterm government bond rate is the 10-year government bond yield. The inflation rate is

\footnotetext{
${ }^{5}$ In addition, we correct standard errors for heteroskedasticity and autocorrelation in the residuals using the method proposed by Newey and West (1987) with a maximum lag length of 6 . The empirical results are robust concerning the number of lags.
} 
proxied by the change in consumer prices. All time series are taken from Global Financial Data.

\section{Empirical Results}

Table 1 summarises the estimation results for the model without control variables and the model with a reduced number of control variables. We report findings for the country-specific full sample period and in addition for the shorter sample 1970-2007 common for all countries to obtain comparable cross country results. Besides the empirical results regarding the Other January Effect, Table 1 also reports the estimated coefficients of the control variables with their $p$-values. In general, statistically significant point estimates have the theoretically expected signs. Coefficients of the Halloween dummy are significant for most of the countries. Among the other control variables, relative interest rate and expected inflation are the most influential ones. Moreover, national excess returns are, in general, positively correlated with the U.S. stock market. Across most countries and model specifications, the empirical results are largely robust to statistical inference with standard $p$-values or bootstrapped ones. ${ }^{6}$

\section{Insert Table 1 about here}

More important, for the U.S., monthly excess stock market returns are, on average, higher by $0.73 \%$ over the full sample ( $1.01 \%$ over the short sample) following positive Januarys than after Januarys scoring negative returns. This result is statistically significant at the $1 \%$ level (5\% level) and consistent with Cooper et al. (2006). While the Other January Effect is significant and remarkably large for the U.S., it vanishes as the sample is extended internationally. In particular, the countries with stock markets that are not subject to the Other January Effect are Australia, Austria, Belgium, Canada, Denmark, France, Germany, Italy, Japan, the Netherlands, South Africa, South Korea, and Sweden. By contrast, Finland, Norway, Spain, Switzerland and the U.K. exhibit the Other January Effect. For Finland and Switzerland the Other January Effect is insignificant when estimated without using control variables. The Other January Effect in Spain is not present in the model with control variables. In the U.K., the Other January Effect is more prominent in the recent sample compared to the 1924-2007 period.

\footnotetext{
${ }^{6}$ Empirical results on the randomized-bootstrap inference are not reported but are available on request.
} 
Additionally, as a robustness check, we investigate the predictive power of stock returns in each of the remaining calendar months from February to December. ${ }^{7}$ It turns out that some other calender months in a few countries have statistically significant predictive power for the following eleven months with magnitudes comparable to the results we report for the Other January Effect. Nevertheless, a consistent and robust pattern across months or countries cannot be identified.

The empirical evidence reported by Cooper et al. (2006) on the Other January Effect is sensitive to the selection of the sample period. While the anomaly is significant for the full sample (1973-2003), it disappears in non-overlapping 10-year subperiods from 1980 onwards. Therefore, as a further robustness check, we investigate the predictive power of each month by country over subperiods. ${ }^{8}$ The results of Cooper et al. (2006) are confirmed for our data set, too. As for the U.S. the Other January Effect disappears for Finland, Spain and the U.K. in the seventies. Only for Norway and Switzerland, the Other January Effect is statistical significant over time. Moreover, there are very few countries in which a particular month has predictive power throughout all subperiods. For most countries the predictive power of particular months varies over time.

In summary, the Other January Effect is an American peculiarity and cannot be detected for most of the remaining 18 stock markets in our dataset. In fact, large and highly developed stock markets other than the U.S., such as Japan, France and Germany do not exhibit the Other January Effect. These results give rise to the hypothesis that the Other January Effect is not a widely observed phenomenon.

\section{Summary and Conclusion}

The aim of this paper is to investigate the presence of the Other January Effect in 19 countries. This stock market anomaly stems from the market wisdom 'As January goes, as goes the year' and refers to the observation that U.S. stock market returns in January can serve as a reliable predictor for the market return in the subsequent eleven months. We provide international empirical evidence on the Other January Effect, as existing literature on this anomaly focuses on the U.S. stock market. By including stock markets other than

\footnotetext{
${ }^{7}$ Since January returns are included into those regressions we additionally control for the well-known January Effect. Detailed empirical results are available on request.

${ }^{8}$ Detailed empirical results are available on request.
} 
the U.S. in our sample, data-snooping biases are reduced.

For the U.S., we find evidence in favour of the Other January Effect, which is consistent with the results in Cooper et al. (2006). Among the 18 other countries in our sample, only for Norway and Switzerland the stock market anomaly is statistical significant over various subperiods. Hence, there is no broad and robust empirical evidence in favour of an international Other January Effect. Regarding the forecasting power of the remaining months, we find that January is not unique in its capability to predict stock market returns. In fact, almost every month shows statistically significant forecasting power in at least one of the 19 countries under investigation without a consistent pattern.

In essence, only two out of 19 countries exhibit a robust Other January Effect. The existence of statistically significant forecasting power of particular months seems to be determined by the selection of stock markets or sample periods. Systematically predicting stock returns based on previous return observations appears to be impossible. In light of this evidence, we conclude that the Other January Effect is not an international phenomenon. 


\section{References}

Bloch, H. and R. Pupp (1983). The January barometer revisited and rejected. Journal of Portfolio Managment 9(2), 48-51.

Bouman, S. and B. Jacobsen (2002). The Helloween indicator, "sell in May and go away": Another puzzle. American Economic Review 92(5), 1618-1635.

Brown, L. D. and L. Juo (2006). The January barometer: Further evidence. Journal of Investing 15(1), 25-31.

Campbell, J. Y. and R. J. Shiller (1988). Stock prices, earnings, and expected dividends. Journal of Finance 43(3), 661-676.

Campbell, J. Y. and M. Yogo (2006). Efficient tests of stock return predictability. Journal of Financial Economics 81(1), 27-60.

Chen, N.-F., R. Roll, and S. A. Ross (1986). Economic forces and the stock market. Journal of Business 59(3), 383-403.

Cooper, M. J., J. J. McConnell, and A. V. Octchinnikov (2006). The other January effect. Journal of Financial Economics 82(2), 315-341.

Fama, E. F. (1998). Market efficiency, long-term returns, and behavioral finance. Journal of Financial Economics 49(3), 283-306.

Fama, E. F. and K. R. French (1986). Business conditions and expected returns on stocks and bonds. Journal of Financial Economics 25(1), 23-49.

Fama, E. F. and K. R. French (1988). Dividend yields and expected stock returns. Journal of Financial Economics 22(1), 3-25.

Fuller, R. J. (1978). The January barometer: What's its batting average? Journal of Portfolio Managment 4(2), 5-7.

Hensel, C. R. and W. T. Ziemba (1995a). The January barometer. Journal of Investing 4 (2), $67-70$. 
Hensel, C. R. and W. T. Ziemba (1995b). The January barometer: European, North American, Pacific and worldwide results. Finanzmarkt und Portfolio Management 9(2), $187-196$.

Hirsch, J. A. and Y. Hirsch (2007). The Stock Trader's Almanac. New Jersey: Wiley.

Jensen, G. R., J. M. Mercer, and R. R. Johnson (1996). Business conditions, monetary policy, and expected security returns. Journal of Financial Economics 40(2), 213-237.

Keim, D. B. and R. F. Stambaugh (1986). Prediciting returns in the stock and bond market. Journal of Financial Economics 17(2), 357-390.

Lo, A. W. and A. C. MacKinlay (1990). Data-snooping biases in tests of financial asset pricing models. Review of Financial Studies 3(3), 431-467.

Newey, W. K. and K. D. West (1987). A simple, positive semi-definite, heteroscedasticity and autocorrelation consistent covariance matrix. Econometrica 55(3), 703-708.

Schwert, G. W. (2003). Anomalies and market efficiency. In G. Constantinides, M. Harris, and M. Stulz (Eds.), Handbook of the Economics of Finance, pp. 937-972. Amsterdam: North-Holland.

Sullivan, R., A. Timmermann, and H. White (2001). Dangers of data mining: The case of calendar effects in stock returns. Journal of Econometrics 105(1), 249-286.

Twain, M. (1894). The Tragedy of Pudd'nhead Wilson. The American Publishing Company.

White, H. (1980). A heteroskedasticity-consistent covariance matrix estimator and a direct test for heteroskedasticity. Econometrica 48(4), 817-838. 
Table 1: The Other January Effect

Country Sample period Regression coefficients ( $p$-values)

\begin{tabular}{|c|c|c|c|c|c|c|c|c|c|c|c|}
\hline & & \\
\hline & & \multicolumn{2}{|c|}{$r_{t}=\alpha+\beta O J E_{t}+u_{t}$} & \multicolumn{8}{|c|}{$r_{t}=\alpha+\beta O J E_{t}+\gamma X_{t}+\phi Z_{t-1}+u_{t}$} \\
\hline & & Constant & $O J E_{t}$ & Constant & $O J E_{t}$ & Hall $_{t}$ & $D I V_{t-1}$ & $T E R M_{t-1}$ & $R R E L_{t-1}$ & $I N F_{t-1}^{e}$ & $r_{t-1}^{U S}$ \\
\hline \multirow[t]{2}{*}{$\overline{\overline{\text { Australia }}}$} & $1903: 1-2007: 12$ & $\begin{array}{c}0.34 \\
(0.230)\end{array}$ & $\begin{array}{c}0.22 \\
(0.492)\end{array}$ & $\begin{array}{c}0.50 \\
(0.102)\end{array}$ & $\begin{array}{c}0.27 \\
(0.375)\end{array}$ & 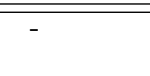 & 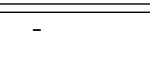 & 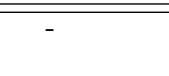 & - & $\begin{array}{l}-0.07 \\
(0.008)^{* * *}\end{array}$ & $\begin{array}{c}0.10 \\
(0.000)^{* * *}\end{array}$ \\
\hline & 1970:1 - 2007:12 & $\begin{array}{l}0.35 \\
(0.347)\end{array}$ & $\begin{array}{c}-0.24 \\
(0.653)\end{array}$ & $\begin{array}{l}0.22 \\
(0.564)\end{array}$ & $\begin{array}{c}-0.24 \\
(0.642)\end{array}$ & - & - & - & - & - & $\begin{array}{l}0.18 \\
(0.005)^{* * *}\end{array}$ \\
\hline$\overline{\text { Austria }}$ & $1970: 1-2007: 12$ & $\begin{array}{c}0.186 \\
(0.556)\end{array}$ & $\begin{array}{c}0.05 \\
(0.923)\end{array}$ & $\begin{array}{l}-0.84 \\
(0.043)^{* *}\end{array}$ & $\begin{array}{c}0.17 \\
(0.717)\end{array}$ & $\begin{array}{l}1.714 \\
(0.000)^{* * *}\end{array}$ & - & - & - & - & $\begin{array}{c}0.22 \\
(0.000)^{* * *}\end{array}$ \\
\hline \multirow[t]{2}{*}{$\overline{\text { Belgium }}$} & $1951: 1-2007: 12$ & $\begin{array}{c}0.25 \\
(0.600)\end{array}$ & $\begin{array}{c}-0.11 \\
(0.832)\end{array}$ & $\begin{array}{c}-0.74 \\
(0.290)\end{array}$ & $\begin{array}{l}0.04 \\
(0.935)\end{array}$ & $\begin{array}{l}1.00 \\
(0.002)^{* * *}\end{array}$ & $\begin{array}{l}0.25 \\
(0.074)^{*}\end{array}$ & - & - & $\begin{array}{l}-0.19 \\
(0.004)^{* * *}\end{array}$ & $\begin{array}{c}0.17 \\
(0.000)^{* * *}\end{array}$ \\
\hline & 1970:1 - 2007:12 & $\begin{array}{l}0.09 \\
(0.875)\end{array}$ & $\begin{array}{l}0.17 \\
(0.778)\end{array}$ & $\begin{array}{c}-0.18 \\
(0.781)\end{array}$ & $\begin{array}{l}0.42 \\
(0.472)\end{array}$ & $\begin{array}{l}1.54 \\
(0.000)^{* * *}\end{array}$ & - & - & - & $\begin{array}{l}-0.17 \\
(0.018)^{* *}\end{array}$ & $\begin{array}{l}0.14 \\
(0.008)^{* * *}\end{array}$ \\
\hline \multirow[t]{2}{*}{$\overline{\text { Canada }}$} & $1936: 1-2007: 12$ & $\begin{array}{l}0.19 \\
(0.530)\end{array}$ & $\begin{array}{l}0.12 \\
(0.733)\end{array}$ & $\begin{array}{c}-0.17 \\
(0.622)\end{array}$ & $\begin{array}{l}-.02 \\
(0.947)\end{array}$ & $\begin{array}{c}0.67 \\
(0.023)^{* *}\end{array}$ & - & - & $\begin{array}{l}-0.27 \\
(0.073)^{*}\end{array}$ & - & $\frac{0.20}{(0.000)^{* * *}}$ \\
\hline & 1970:1 - 2007:12 & $\begin{array}{l}0.25 \\
(0.464) \\
\end{array}$ & $\begin{array}{c}-0.20 \\
(0.663) \\
\end{array}$ & $\begin{array}{c}-0.18 \\
(0.669) \\
\end{array}$ & $\begin{array}{c}-0.31 \\
(0.510) \\
\end{array}$ & $\begin{array}{l}0.89 \\
(0.047)^{* *}\end{array}$ & - & - & $\begin{array}{c}-0.31 \\
(0.081)^{*}\end{array}$ & - & $\begin{array}{l}0.10 \\
(0.037)^{* *}\end{array}$ \\
\hline$\overline{\text { Denmark }}$ & $1970: 1-2007: 12$ & $\begin{array}{l}0.04 \\
(0.939)\end{array}$ & $\begin{array}{c}0.02 \\
(0.976)\end{array}$ & $\begin{array}{c}0.19 \\
(0.763)\end{array}$ & $\begin{array}{c}-0.23 \\
(0.697)\end{array}$ & - & $\begin{array}{c}0.36 \\
(0.055)^{*}\end{array}$ & - & $\begin{array}{l}-0.34 \\
(0.031)^{* *}\end{array}$ & $\begin{array}{l}-0.20 \\
(0.030)^{* *}\end{array}$ & - \\
\hline \multirow[t]{2}{*}{ Finland } & $1963: 1-2007: 12$ & $\begin{array}{c}-0.70 \\
(0.438)\end{array}$ & $\begin{array}{l}1.33 \\
(0.158)\end{array}$ & $\begin{array}{c}-0.87 \\
(0.357)\end{array}$ & $\begin{array}{l}1.84 \\
(0.055)^{*}\end{array}$ & $\begin{array}{l}1.62 \\
(0.003)^{* * *}\end{array}$ & - & - & - & $\begin{array}{l}-0.17 \\
(0.001)^{* * *}\end{array}$ & - \\
\hline & 1970:1 - 2007:12 & $\begin{array}{l}-0.77 \\
(0.522)\end{array}$ & $\begin{array}{l}1.43 \\
(0.246)\end{array}$ & $\begin{array}{c}-0.97 \\
(0.428)\end{array}$ & $\begin{array}{l}2.12 \\
(0.093)^{*}\end{array}$ & $\begin{array}{l}1.66 \\
(0.008)^{* * *}\end{array}$ & - & - & - & $\begin{array}{l}-0.20 \\
(0.000)^{* * *}\end{array}$ & - \\
\hline \multirow[t]{2}{*}{$\overline{\text { France }}$} & $1896: 1-2007: 12$ & $\begin{array}{c}0.43 \\
(0.140)\end{array}$ & $\begin{array}{c}-0.15 \\
(0.654)\end{array}$ & $\begin{array}{c}-0.41 \\
(0.259)\end{array}$ & $\begin{array}{l}-.05 \\
(0.884)\end{array}$ & $\begin{array}{c}0.90 \\
(0.032)^{* *}\end{array}$ & - & $\begin{array}{l}0.26 \\
(0.031)^{* *}\end{array}$ & - & - & $\begin{array}{l}0.10 \\
(0.001)^{* * *}\end{array}$ \\
\hline & 1970:1 - 2007:12 & $\begin{array}{l}0.49 \\
(0.421)\end{array}$ & $\begin{array}{l}-0.51 \\
(0.452)\end{array}$ & $\begin{array}{l}-4.03 \\
(0.000)^{* * *}\end{array}$ & $\begin{array}{l}0.23 \\
(0.726)\end{array}$ & $\begin{array}{l}1.82 \\
(0.001)^{* * *}\end{array}$ & $\begin{array}{l}1.67 \\
(0.000)^{* * *}\end{array}$ & - & - & $\begin{array}{l}-0.71 \\
(0.000)^{* * *}\end{array}$ & $\begin{array}{l}0.15 \\
(0.022)^{* *}\end{array}$ \\
\hline \multirow[t]{2}{*}{$\overline{\text { Germany }}$} & $\begin{array}{l}1870: 1-2007: 12 \\
(\text { ex 1922-1924) }\end{array}$ & $\begin{array}{c}-0.36 \\
(0.249)\end{array}$ & $\begin{array}{c}0.39 \\
(0.402)\end{array}$ & $\begin{array}{l}-1.40 \\
(0.004)^{* * *}\end{array}$ & $\begin{array}{l}0.49 \\
(0.305)\end{array}$ & $\begin{array}{c}0.83 \\
(0.040)^{* *}\end{array}$ & - & $\begin{array}{l}0.37 \\
(0.007)^{* * *}\end{array}$ & - & - & $\begin{array}{c}0.08 \\
(0.008)^{* * *}\end{array}$ \\
\hline & $1970: 1-2007: 12$ & $\begin{array}{c}0.08 \\
(0.887)\end{array}$ & $\begin{array}{l}0.12 \\
(0.842)\end{array}$ & $\begin{array}{c}-0.52 \\
(0.364)\end{array}$ & $\begin{array}{l}0.04 \\
(0.940)\end{array}$ & $\begin{array}{l}1.15 \\
(0.021)^{* *}\end{array}$ & - & - & $\begin{array}{l}-0.53 \\
(0.027)^{* *}\end{array}$ & - & $\begin{array}{l}0.16 \\
(0.017)^{* *}\end{array}$ \\
\hline \multirow[t]{2}{*}{$\overline{\text { Italy }}$} & $1926: 1-2007: 12$ & $\begin{array}{c}0.74 \\
(0.141)\end{array}$ & $\begin{array}{c}-0.85 \\
(0.135)\end{array}$ & $\begin{array}{c}0.68 \\
(0.179)\end{array}$ & $\begin{array}{l}-.93 \\
(0.103)\end{array}$ & - & - & - & $\begin{array}{c}-0.42 \\
(0.074)^{*}\end{array}$ & - & $\frac{0.14}{(0.001)^{* * *}}$ \\
\hline & 1970:1 - 2007:12 & $\begin{array}{c}-1.13 \\
(0.081)^{*}\end{array}$ & $\begin{array}{l}1.05 \\
(0.158)\end{array}$ & $\begin{array}{l}-1.83 \\
(0.013)^{* *}\end{array}$ & $\begin{array}{l}0.87 \\
(0.241)\end{array}$ & $\begin{array}{l}1.53 \\
(0.015)^{* *}\end{array}$ & - & - & - & - & $\begin{array}{l}0.19 \\
(0.008)^{* * *}\end{array}$ \\
\hline \multirow[t]{2}{*}{ Japan } & 1931:1 - 2007:12 & $\begin{array}{c}0.06 \\
(0.888)\end{array}$ & $\begin{array}{c}0.72 \\
(0.128)\end{array}$ & $\begin{array}{l}-1.14 \\
(0.030)^{* *}\end{array}$ & $\begin{array}{l}0.57 \\
(0.226)\end{array}$ & $\begin{array}{l}1.14 \\
(0.005)^{* * *}\end{array}$ & $\begin{array}{l}0.22 \\
(0.004)^{* * *}\end{array}$ & - & - & - & - \\
\hline & 1970:1 - 2007:12 & $\begin{array}{c}-0.13 \\
(0.799)\end{array}$ & $\begin{array}{c}0.54 \\
(0.343)\end{array}$ & $\begin{array}{l}-1.68 \\
(0.035)^{* *}\end{array}$ & $\begin{array}{c}0.73 \\
(0.204)\end{array}$ & $\begin{array}{l}1.36 \\
(0.008)^{* * *}\end{array}$ & $\begin{array}{l}1.14 \\
(0.013)^{* *}\end{array}$ & - & - & $\begin{array}{l}-0.19 \\
(0.005)^{* * *}\end{array}$ & - \\
\hline \multirow[t]{2}{*}{$\overline{\text { Netherlands }}$} & $1952: 1-2007: 12$ & $\begin{array}{c}0.31 \\
(0.499)\end{array}$ & $\begin{array}{l}0.16 \\
(0.751)\end{array}$ & $\begin{array}{c}0.11 \\
(0.846)\end{array}$ & $\begin{array}{l}0.44 \\
(0.380)\end{array}$ & $\begin{array}{l}1.44 \\
(0.000)^{* * *}\end{array}$ & - & - & $\begin{array}{l}-0.55 \\
(0.001)^{* * *}\end{array}$ & $\begin{array}{l}-0.21 \\
(0.002)^{* * *}\end{array}$ & $\begin{array}{l}0.13 \\
(0.021)^{* *}\end{array}$ \\
\hline & 1970:1 - 2007:12 & $\begin{array}{c}0.01 \\
(0.992) \\
\end{array}$ & $\begin{array}{l}0.47 \\
(0.456) \\
\end{array}$ & $\begin{array}{c}-0.35 \\
(0.609) \\
\end{array}$ & $\begin{array}{l}1.00 \\
(0.117)\end{array}$ & $\begin{array}{l}1.72 \\
(0.000)^{* * *}\end{array}$ & - & - & $\begin{array}{l}-0.58 \\
(0.001)^{* * *}\end{array}$ & $\begin{array}{l}-0.25 \\
(0.003)^{* * *}\end{array}$ & $\begin{array}{c}0.13 \\
(0.069)^{*}\end{array}$ \\
\hline
\end{tabular}


Table 1 (continued): The Other January Effect

\begin{tabular}{|c|c|c|c|c|c|c|c|c|c|c|c|}
\hline \multirow[t]{3}{*}{ Country } & \multirow[t]{3}{*}{ Sample period } & \multicolumn{10}{|c|}{ Regression coefficients ( $p$-values) } \\
\hline & & \multicolumn{2}{|c|}{$r_{t}=\alpha+\beta O J E_{t}+u_{t}$} & \multicolumn{8}{|c|}{$r_{t}=\alpha+\beta O J E_{t}+\gamma X_{t}+\phi Z_{t-1}+u_{t}$} \\
\hline & & Constant & $O J E_{t}$ & Constant & $O J E_{t}$ & HallD $_{t}$ & $D I V_{t-1}$ & $T E R M_{t-1}$ & $R R E L_{t-1}$ & $I N F_{t-1}^{e}$ & $r_{t-1}^{U S}$ \\
\hline$\overline{\text { Norway }}$ & 1970:1 - 2007:12 & $\begin{array}{c}-0.87 \\
(0.153)\end{array}$ & $\begin{array}{l}1.25 \\
(0.088)^{*}\end{array}$ & $\begin{array}{l}-2.87 \\
(0.013)^{* *}\end{array}$ & $\begin{array}{l}2.12 \\
(0.004)^{* * *}\end{array}$ & 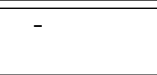 & $\begin{array}{l}1.25 \\
(0.001)^{* * *}\end{array}$ & 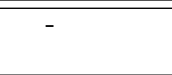 & 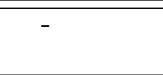 & $\begin{array}{l}-0.43 \\
(0.000)^{* * *}\end{array}$ & $\begin{array}{c}0.16 \\
(0.097)^{*}\end{array}$ \\
\hline \multirow[t]{2}{*}{ South Africa } & 1961:1 - 2007:12 & $\begin{array}{l}0.58 \\
(0.203)\end{array}$ & $\begin{array}{c}-0.04 \\
(0.946)\end{array}$ & $\begin{array}{c}-1.76 \\
(0.079)\end{array}$ & $\begin{array}{l}-.07 \\
(0.909)\end{array}$ & $\begin{array}{l}1.16 \\
(0.034)^{* *}\end{array}$ & $\begin{array}{l}0.51 \\
(0.030)^{* *}\end{array}$ & - & $\begin{array}{l}-0.39 \\
(0.057)^{*}\end{array}$ & - & - \\
\hline & 1970:1 - 2007:12 & $\begin{array}{c}0.57 \\
(0.222)\end{array}$ & $\begin{array}{c}-0.14 \\
(0.826)\end{array}$ & $\begin{array}{c}-1.70 \\
(0.101)\end{array}$ & $\begin{array}{c}-0.27 \\
(0.693)\end{array}$ & $\begin{array}{l}1.14 \\
(0.074)^{*}\end{array}$ & $\begin{array}{l}0.50 \\
(0.044)^{* *}\end{array}$ & - & $\begin{array}{l}-0.40 \\
(0.063)^{*}\end{array}$ & - & - \\
\hline \multirow[t]{2}{*}{ South Korea } & 1964:1 - 2007:12 & $\begin{array}{c}0.23 \\
(0.731)\end{array}$ & $\begin{array}{c}0.48 \\
(0.559)\end{array}$ & $\begin{array}{c}0.31 \\
(0.618)\end{array}$ & $\begin{array}{l}-.18 \\
(0.822)\end{array}$ & - & $\begin{array}{c}0.24 \\
(0.006)^{*}\end{array}$ & - & $\begin{array}{l}-0.51 \\
(0.001)^{* * *}\end{array}$ & $\begin{array}{c}-0.17 \\
(0.064)^{*}\end{array}$ & - \\
\hline & 1970:1 - 2007:12 & $\begin{array}{l}0.16 \\
(0.732) \\
\end{array}$ & $\begin{array}{l}0.54 \\
(0.456) \\
\end{array}$ & $\begin{array}{l}0.05 \\
(0.937) \\
\end{array}$ & $\begin{array}{l}0.01 \\
(0.992) \\
\end{array}$ & - & $\begin{array}{l}0.19 \\
(0.042)^{* *}\end{array}$ & - & $\begin{array}{l}-0.71 \\
(0.001)^{* * *}\end{array}$ & $\begin{array}{l}-0.12 \\
(0.088)^{*}\end{array}$ & - \\
\hline \multirow[t]{2}{*}{ Spain } & $1952: 1-2007: 12$ & $\begin{array}{c}-0.46 \\
(0.264)\end{array}$ & $\begin{array}{c}1.10 \\
(0.020)^{* *}\end{array}$ & $\begin{array}{c}-0.20 \\
(0.747)\end{array}$ & $\begin{array}{l}0.70 \\
(0.143)\end{array}$ & $\begin{array}{l}0.98 \\
(0.013)^{* *}\end{array}$ & - & $\begin{array}{c}0.24 \\
(0.088)^{*}\end{array}$ & - & $\begin{array}{l}-0.13 \\
(0.001)^{* * *}\end{array}$ & $\begin{array}{l}0.15 \\
(0.007)^{* * *}\end{array}$ \\
\hline & 1970:1 - 2007:12 & $\begin{array}{c}-0.64 \\
(0.203) \\
\end{array}$ & $\begin{array}{l}1.16 \\
(0.054)^{*}\end{array}$ & $\begin{array}{l}-0.51 \\
(0.9538) \\
\end{array}$ & $\begin{array}{c}0.63 \\
(0.314) \\
\end{array}$ & $\begin{array}{l}1.35 \\
(0.012)^{* *}\end{array}$ & - & $\begin{array}{l}0.32 \\
(0.075)^{*}\end{array}$ & - & $\begin{array}{l}-0.15 \\
(0.012)^{* *}\end{array}$ & $\begin{array}{l}0.18 \\
(0.005)^{* * *}\end{array}$ \\
\hline \multirow[t]{2}{*}{ Sweden } & 1919:1 - 2007:12 & $\begin{array}{c}-0.15 \\
(0.723)\end{array}$ & $\begin{array}{c}0.51 \\
(0.267)\end{array}$ & $\begin{array}{c}-0.46 \\
(0.306)\end{array}$ & $\begin{array}{c}0.45 \\
(0.322)\end{array}$ & $\begin{array}{l}0.66 \\
(0.040)^{* *}\end{array}$ & - & - & $\begin{array}{l}-0.35 \\
(0.012)^{* *}\end{array}$ & - & $\begin{array}{c}0.06 \\
(0.094)^{*}\end{array}$ \\
\hline & 1970:1 - 2007:12 & $\begin{array}{c}0.19 \\
(0.822) \\
\end{array}$ & $\begin{array}{l}0.25 \\
(0.780) \\
\end{array}$ & $\begin{array}{c}-1.95 \\
(0.116) \\
\end{array}$ & $\begin{array}{c}-0.01 \\
(0.995) \\
\end{array}$ & $\begin{array}{l}1.88 \\
(0.002)^{* * *}\end{array}$ & $\begin{array}{l}0.82 \\
(0.020)^{* *}\end{array}$ & - & $\begin{array}{l}-0.47 \\
(0.004)^{* * *}\end{array}$ & $\begin{array}{l}-0.22 \\
(0.070)^{*}\end{array}$ & $\begin{array}{l}0.18 \\
(0.035)^{* *}\end{array}$ \\
\hline Switzerland & 1970:1 - 2007:12 & $\begin{array}{c}-0.18 \\
(0.666)\end{array}$ & $\begin{array}{c}0.69 \\
(0.163)\end{array}$ & $\begin{array}{c}-0.08 \\
(0.891)\end{array}$ & $\begin{array}{c}0.85 \\
(0.075)^{*}\end{array}$ & $\begin{array}{l}0.84 \\
(0.052)^{*}\end{array}$ & - & - & $\begin{array}{l}-0.29 \\
(0.099)^{*}\end{array}$ & $\begin{array}{l}-0.24 \\
(0.020)^{* *}\end{array}$ & $\begin{array}{c}0.15 \\
(0.018)^{* *}\end{array}$ \\
\hline \multirow[t]{2}{*}{$\overline{\mathrm{U} . \mathrm{K}}$} & $1924: 1-2007: 12$ & $\begin{array}{c}-0.15 \\
(0.649)\end{array}$ & $\begin{array}{c}0.63 \\
(0.095)^{*}\end{array}$ & $\begin{array}{c}-0.56 \\
(0.121)\end{array}$ & $\begin{array}{c}0.52 \\
(0.161)\end{array}$ & $\begin{array}{l}0.82 \\
(0.006)^{* * *}\end{array}$ & - & - & - & - & $\frac{0.14}{(0.001)^{* * *}}$ \\
\hline & 1970:1 - 2007:12 & $\begin{array}{l}-0.87 \\
(0.090)^{*}\end{array}$ & $\begin{array}{l}1.49 \\
(0.013)^{* *}\end{array}$ & $\begin{array}{l}-3.76 \\
(0.015)^{* *}\end{array}$ & $\begin{array}{l}1.60 \\
(0.007)^{* * *}\end{array}$ & $\begin{array}{l}1.56 \\
(0.002)^{* * *}\end{array}$ & $\begin{array}{l}0.75 \\
(0.091)^{*}\end{array}$ & - & - & $\begin{array}{l}-0.17 \\
(0.049)^{* *}\end{array}$ & - \\
\hline \multirow[t]{2}{*}{ U.S. } & $1872: 1-2007: 12$ & $\begin{array}{c}-0.18 \\
(0.450)\end{array}$ & $\begin{array}{l}0.70 \\
(0.012)^{* *}\end{array}$ & $\begin{array}{c}-0.29 \\
(0.210)\end{array}$ & $\begin{array}{l}0.73 \\
(0.009)^{* * *}\end{array}$ & - & - & $\begin{array}{l}0.19 \\
(0.004)^{* * *}\end{array}$ & - & - & - \\
\hline & 1970:1 - 2007:12 & $\begin{array}{c}-0.38 \\
(0.313)\end{array}$ & $\begin{array}{l}1.10 \\
(0.016)^{* *}\end{array}$ & $\begin{array}{l}-1.41 \\
(0.054)^{*}\end{array}$ & $\begin{array}{l}1.01 \\
(0.027)^{* *}\end{array}$ & $\begin{array}{l}0.77 \\
(0.061)^{*}\end{array}$ & $\begin{array}{l}0.62 \\
(0.011)^{* *}\end{array}$ & - & $\begin{array}{l}-0.35 \\
(0.090)^{*}\end{array}$ & $\begin{array}{l}-0.26 \\
(0.024)^{* *}\end{array}$ & - \\
\hline
\end{tabular}

Notes: The values in parentheses are $p$-values using heteroskedasticity-consistent standard errors proposed by White $(1980) .{ }^{*}, * *, * * *$ denote statistical significance at the $10 \%, 5 \%$ and $1 \%$ level, respectively. 